\title{
Species biology of elasmobranch by-catch in bottom-trawl fishery on the northern Patagonian shelf, Argentina
}

\author{
A. C. Crespi-Abril*, S. N. Pedraza, N. A. García, E. A. Crespo \\ Centro Nacional Patagónico (CONICET), Boulevard Brown s/n, Puerto Madryn, Chubut 9120, Argentina
}

\begin{abstract}
The present study analyzes the species composition of elasmobranch by-catch of bottom trawlers that targeted common hake Merluccius hubbsi on the northern and central Patagonian shelf during 2001, 2002 and 2003. Six surveys were conducted, and a total of 20 species of elasmobranchs were observed. Zearaja chilensis and Squalus acanthias were present in all surveys. The mean values of relative abundance ranged between 9.12 and 151 ind. $\mathrm{km}^{-2}$ for $Z$. chilensis and between 8.24 and 298 ind. $\mathrm{km}^{-2}$ for $S$. acanthias. Bathyraja brachyurops, B. macloviana, B. magellanica, Discopyge sp. and Psammobatis lentiginosa were registered only in 1 survey, and their relative abundance did not exceed 15 ind. $\mathrm{km}^{-2}$. There were no patterns detected between the mean size of the individuals and the depth of capture for any of the captured species. Length-to-weight relationships were estimated for 14 species, and size-at-maturity was estimated for 8 species.
\end{abstract}

KEY WORDS: By-catch · Size-at-maturity $\cdot$ Elasmobranchs $\cdot$ Length-to-weight relationships

\section{INTRODUCTION}

Elasmobranchs are particularly vulnerable to overexploitation. Their K-selected life-history strategy results in low growth rates and low resilience to fishing mortality (Hoenig \& Gruber 1990, Frisk et al. 2001). Thus, management of any fishery that captures sharks and skates, either directly (target species) or indirectly (by-catch), must consider the impact on their populations to avoid overfishing and population decline (Cortés 2000). A decrease in elasmobranch abundance may directly (i.e. reducing predation) or indirectly (i.e. reducing competition) affect other species of the marine community (Stevens et al. 2000, Shepherd \& Myers 2005, Ruocco et al. 2012), since they are key species in most ecosystems (Stevens et al. 2000). Despite the key role that elasmobranchs play in ecosystems, the basic biological information needed for responsible management is lacking for many species, including minimum, maximum and average sizes, age-at-maturity estimations and length- to-weight relationships. These data are essential for understanding growth rate, age structure and other aspects of elasmobranch population dynamics. In Argentine waters, studies on elasmobrachs have been neglected, but in the last $10 \mathrm{yr}$ this situation has changed (Lasta 2003). This new data led to the creation in 2007 of a national plan of action for elasmobranch conservation and management (Perez Comesaña et al. 2011). The first step in this plan was to carefully review the available information on several species and to identify knowledge gaps in order to determine key lines of research (Perez Comesaña et al. 2011). In this context, the amount of information available and the number of works published increased significantly (Lasta 2003, Colonello et al. 2011, Perez Comesaña et al. 2011) in an effort to increase baseline information on elasmobranchs. Several of these studies involved the analysis of reproductive and trophic characteristics (Lucifora et al. 1999, Koen Alonso et al. 2001, Crespi-Abril et al. 2003, Elías et al. 2005, Ruocco et al. 2006, Scenna 2011). 
Bottom-trawl fishery uses non-selective gear (Kelleher 2005) and captures several non-target species. In Argentina, bottom trawling is practiced over the Argentine shelf to capture the common hake Merluccisus hubbsi (Marini, 1933). This resource sustains one of the most important fisheries in Argentina in terms of both landings and fishing effort. Since the early 1980s the main fishing grounds of this fishery (where most of the fishing effort is located) are in the Patagonian region (south of $41^{\circ} \mathrm{S}$ ) (Bezzi et al. 1994, Aubone et al. 2004). Elasmobranchs are a common but unspecified by-catch in this fishery as they are in many of bottom-trawl fisheries worldwide (Stevens et al. 2000, Kelleher 2005). Unfortunately, few speciesspecific data from elasmobranchs are available on the main fishing grounds of northern Patagonia, and less is known about the status of each stock affected. However, recently, large annual landings of elasmobranchs have been a cause of concern in Argentina. Only a few studies have focused on evaluating the fraction of the population that is affected by the fisheries in Argentina (Chiaramonte 1998, Perez Comesaña et al. 2011). Up to present, no studies have been conducted to determine the species of elasmobranchs affected by the common-hake bottom-trawl fishery. In order to address this situation, the objectives of this paper are to report elasmobranch species affected by the common-hake bottom-trawl fishery that operates in northern Patagonia and to provide baseline information on sex ratios, estimations of the species' sizeat-maturity (whenever this was possible), and the proportion of mature individuals captured.

\section{MATERIALS AND METHODS}

\section{Fishing methods and study area}

Surveys were conducted on board 3 vessels of $42 \mathrm{~m}$ in length and $1200 \mathrm{HP}$ in engine power equipped with bottom-trawl nets. The opening of each net was approximately $30 \mathrm{~m}$ wide and $3 \mathrm{~m}$ in height, and the mesh size was $120 \mathrm{~mm}$. Vessels fit in Category IV of the bottom-trawl fleet that fishes common hake Merluccius hubbsi which represents $>70 \%$ of the total fishing effort in the studied area (Sánchez et al. 2011). Surveys were conducted on the Argentine shelf between 41 and $47^{\circ} \mathrm{S}$ in a depth range of 60 to $120 \mathrm{~m}$ (Fig. 1), which is the major fishing ground for bottom trawlers. Also, this area comprises the most important reproductive ground for common hake (Pájaro et al. 2005); thus, a permanent closure is in place to protect juveniles (Fig. 1).

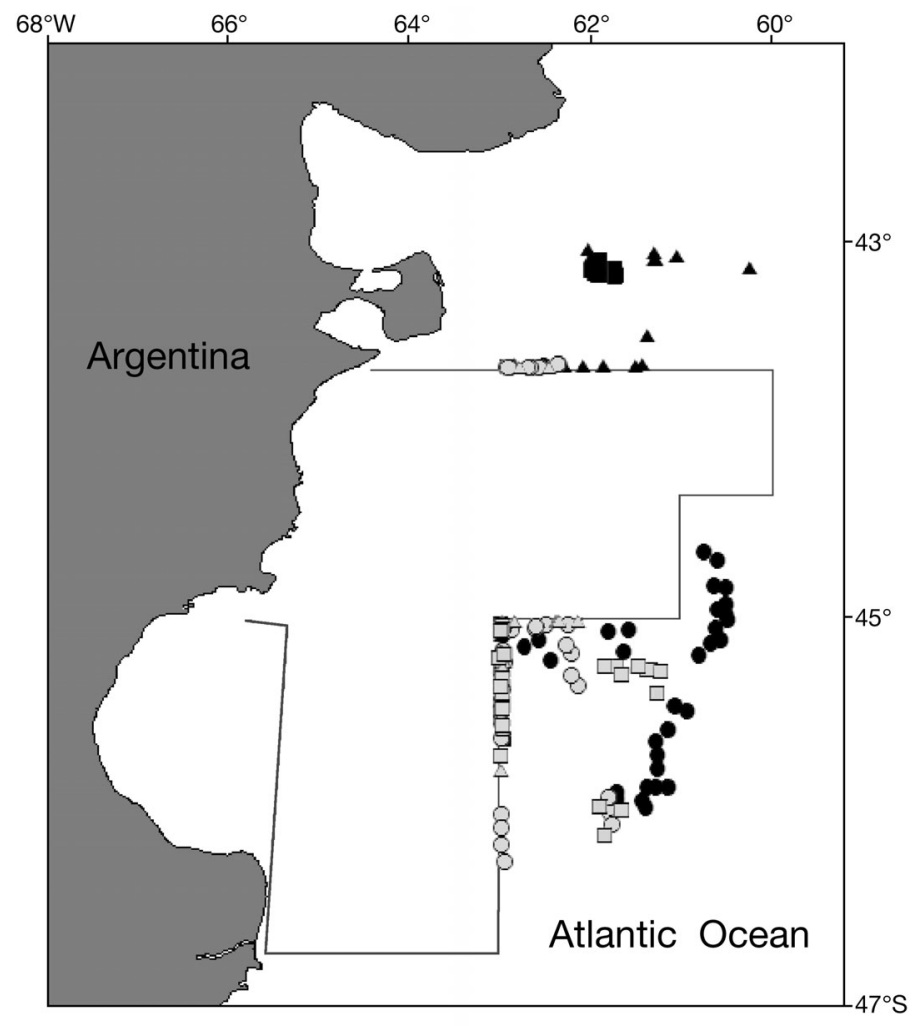

Fig. 1. Map of the study area and the different surveys. September 2001; $\boldsymbol{\Delta}:$ December 2001; $\boldsymbol{\square}:$ March 2002; O: August 2002; $\triangle$ : January 2003; $\square$ : July 2003. The area enclosed by the black line represents the permanent closure for the Merluccius hubbsi fishery

\section{Data collection}

Six surveys were carried out in September and December 2001, March and August 2002, and January and July 2003 (Fig. 1), and a total of 57 tows were analyzed (8 in September 2001, 6 in December 2001, 6 in March 2002, 14 in August 2002, 17 in January 2003, and 6 in July 2003). The duration of each tow was $4 \mathrm{~h}$, and towing speed was approximately 4 knots $\left(7.2 \mathrm{~km} \mathrm{~h}^{-1}\right)$. In each tow, elasmobranchs were identified using species keys (Menni et al. 1984, Cousseau et al. 2000). Specimens were sexed, and total length (TL, cm) was measured on board. In order to determine the proportion of mature animals captured, individual maturity was determined on board by direct observation of the macroscopic gonad status. Females were considered mature when the ovaries presented large and yellowish oocytes, oviducts were well developed and oviductal glands were large (>2 mm maximum width) and whitish (Colonello et al. 2011). In the case of males, the criteria for de- 
fining sexual maturity were wide and rose-colored testes, the presence of seminal fluid in the spermatic ampulla, the presence of a coiling epididymis and the claspers were longer than the tips of posterior pelvic fin-lobes, with the skeleton hardened and the axial cartilages hardened and pointed (Colonello et al. 2011).

\section{Statistical analysis}

The size-at-maturity of species was calculated as the proportion of mature males and females in $1 \mathrm{~cm}$ TL classes (TL50\%). For both sexes, a logistic curve of maturity was fitted by regression to the proportion of mature individuals in the size classes using the least-square method and the relationship:

$$
P_{i}=\frac{1}{1+\mathrm{e}^{-\left(a+b^{*} \mathrm{TL}_{i}\right)}}
$$

where $P_{i}$ and $\mathrm{TL}_{i}$ are, respectively, the proportion of mature individuals and the mantle length of size class ' $i$ ', and $a$ and $b$ are constants. Size-at-maturity was calculated as TL50 $\%=-a / b$, and goodness-offit of the model was tested with a generalized linear model (GLM), assuming a binomial distribution of the data and using a logit link-function. Additionally, sex proportions during each survey were estimated and differences from a 1:1 ratio were analyzed using the binomial test. Data regarding tow duration and speed were recorded to estimate the relative abundance of each species, expressed as the number of individuals per $\mathrm{km}^{2}$ swept area. The frequency of occurrence of each species was estimated as:

$$
\% \mathrm{FO}_{i}=\frac{T_{j}}{T} \times 100
$$

where $\% \mathrm{FO}_{j}$ is the frequency of occurrence of species ' $j$ ' expressed as percentage, $T_{i}$ is the number of tows on which the species ' $j$ ' was present and $T$ is the number of tows analyzed. In order to analyze the mean size variation as a function of depth, the Friedman test for multiple dependent samples was performed for each species. For this test, the variable 'depth' was categorized in ranges of $10 \mathrm{~m}$. For each species, the length-weight relationship was fitted by a linear regression using the least-square method on the natural logarithm of the variables. Model comparisons between sexes were made by analysis of covariance. Also, the hypothesis of isometric growth was tested using Student's $t$-test for slope comparisons.

\section{RESULTS}

\section{Relative abundance}

Twenty species of elasmobranchs were recorded (Table 1). The relative abundance and frequency of occurrence of species were variable (Tables 2 \& 3). Zearaja chilensis and Squalus acanthias were the only species present in all surveys and were present in $>90 \%$ of the tows analyzed, reaching values of relative abundance $>140$ ind. $\mathrm{km}^{-2}$ (Table 2). No spatial aggregation was observed for either species (Fig. 2). The major abundances of $Z$. chilensis were observed in autumn and winter, and the major abundances of $S$. acanthias were observed in winter and spring (Table 2). Schroederichthys bivius, Psammobatis normani and Psammobatis rudis were present in 5 out of 6 surveys, and their frequencies were lower (\%FO between 60 and $80 \%$; Table 3). Their relative abundances were $<45$ ind. $\mathrm{km}^{-2}$ (Table 2). The first 2 species presented a marked spatial aggregation and were more abundant in the southern region of the studied area (Fig. 2). The highest abundances were observed in winter and spring for both species (Table 2). Conversely, $P$. rudis was present in the northern and southern region of the studied area (Fig. 2), and the highest abundances were observed in autumn and winter (Table 2). The presence of Bathyraja albomaculata, B. macloviana, B. scaphiops, Atlantoraja cyclophora, Myliobatis sp., Amblyraja doellojuradoi, and S. guggenheim was sporadic throughout the samples. They were recorded in 1 of the 6 surveys with low values of $\% F O \quad(<14 \%$; Table 3 ), and the relative abundance was $<45$ ind. $\mathrm{km}^{-2}$ (Table 2).

\section{Length-to-weight relationship}

Length-to-weight relationship was estimated for 14 species (Table 4). The covariance analysis revealed no significant differences in the length-to-weight relationships between males and females for any of the species (Table 4); therefore, 1 equation was used for each species, and the parameters were calculated using both sexes combined (Table 4). Six species presented allometric growth type (Table 4).

\section{Size structure, sex proportion and size-at-maturity}

The smallest individual captured was $21 \mathrm{~cm}$ TL (Zearaja chilensis; Fig. 3) and the largest was $120 \mathrm{~cm}$ 
Table 1. List of elasmobranchs captured by bottom-trawl fishery and number of individuals (M: males; F: females) captured in each survey. *Surveys where the proportion of sexes was significantly different from 1:1

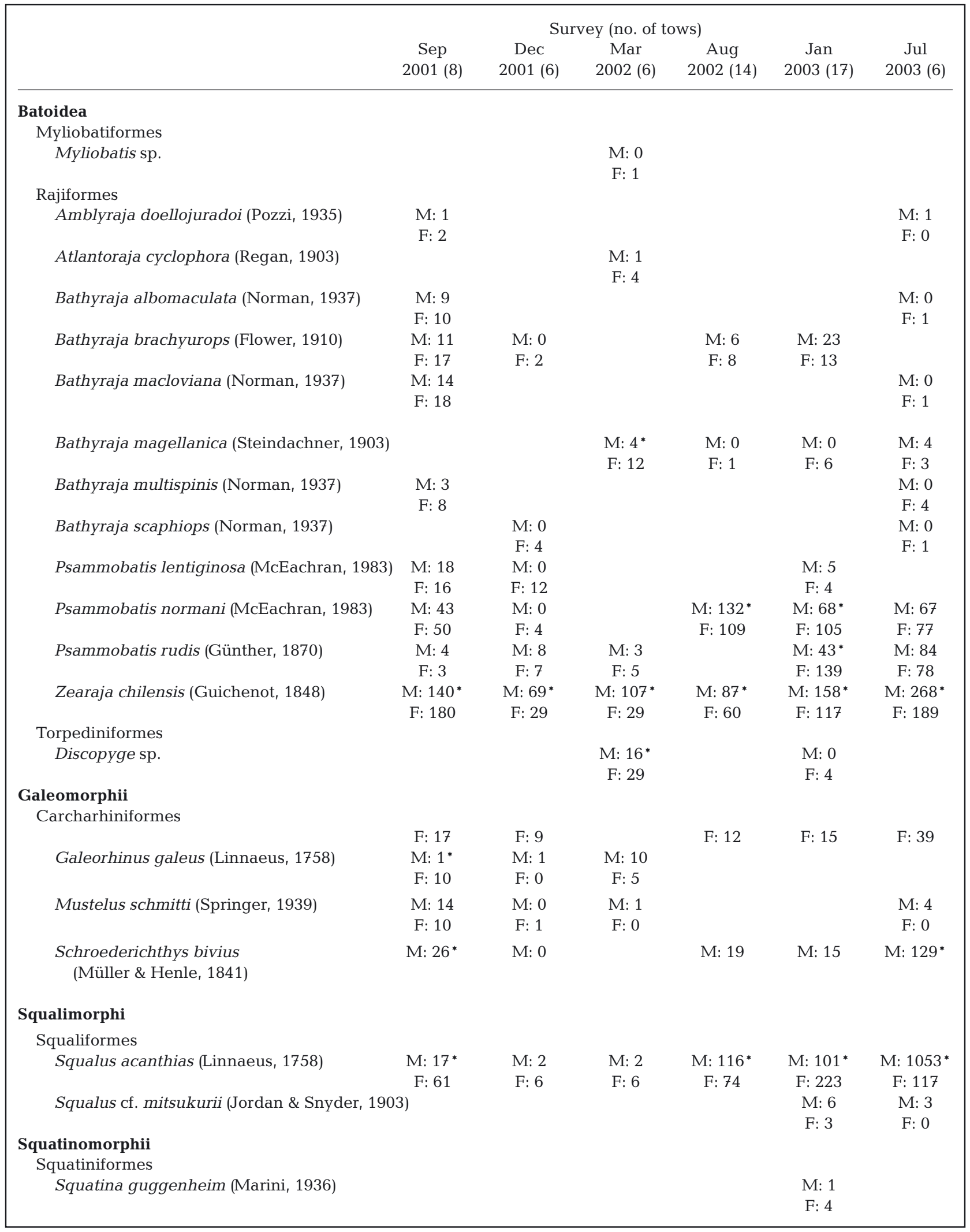


Table 2. Mean relative abundance (ind. $\mathrm{km}^{-2}$ ) of elasmobranch species and mean relative abundance $\left(\mathrm{kg} \mathrm{km}^{-2}\right)$ of $M e r l u c c i u s ~ h u b b s i$ captured in the surveys conducted on the Patagonian shelf. Standard error is shown in parentheses

\begin{tabular}{|c|c|c|c|c|c|c|}
\hline Species & Sep 2001 & Dec 2001 & Mar 2002 & Aug 2002 & Jan 2003 & Jul 2003 \\
\hline Amblyraja doellojuradoi & $4.39(1.39)$ & & & & & $1.53(0.21)$ \\
\hline Bathyraja albomaculata & $5.00(0.62)$ & & & & & $1.34(0.20)$ \\
\hline Bathyraja brachyurops & $8.29(2.65)$ & $1.90(0.30)$ & & $11.20(9.49)$ & $8.98(7.94)$ & \\
\hline Bathyraja macloviana & $10.28(7.49)$ & & & & & $1.57(0.21)$ \\
\hline Bathyraja scaphiops & & $5.61(0.61)$ & & & & $1.48(0.14)$ \\
\hline Discopyge sp. & & & $4.62(3.33)$ & & $1.58(0.01)$ & \\
\hline Galeorhinus galeus & $1.89(0.23)$ & $0.97(0.09)$ & $27.22(10.08)$ & & & \\
\hline Mustelus schmitti & $47.87(27.05)$ & $1.38(0.4)$ & $1.81(0.51)$ & & & $8.24(5.60)$ \\
\hline Myliobatis sp. & & & $1.81(0.15)$ & & & \\
\hline Psammobatis lentiginosa & $11.06(1.32)$ & $4.16(1.32)$ & & & $6.20(2.64)$ & \\
\hline Squalus cf. mitsukurii & & & & & $1.38(0.12)$ & $1.57(1.01)$ \\
\hline Squatina guggenheim & & & & & $1.38(1.21)$ & \\
\hline Zearaja chilensis & $64.44(38.27)$ & $34.68(10.14)$ & $141.1(73.81)$ & $113.2(52.17)$ & $9.12(1.52)$ & $113.6(11.43)$ \\
\hline \multicolumn{7}{|l|}{ Target fish } \\
\hline Merluccius hubbsi & $\begin{array}{l}6563.24 \\
(709.31)\end{array}$ & $\begin{array}{l}4580.69 \\
(596.66)\end{array}$ & $\begin{array}{c}13421.06 \\
(138.52)\end{array}$ & $\begin{array}{c}9446.29 \\
(1300.87)\end{array}$ & $\begin{array}{l}5004.86 \\
(672.85)\end{array}$ & $\begin{array}{l}6175.18 \\
(481.52)\end{array}$ \\
\hline
\end{tabular}

TL (Galeorhinus galeus and Myliobatis sp.). The mean size of all species was $>35 \mathrm{~cm}$. Mature individuals represented $>50 \%$ of the total captured for all species except in Bathyraja brachyurops, G. galeus, Atlantoraja cyclophora and Z. chilensis and in females of Schroederichthys bivius (Table 3). Particularly, B. scaphiops, Discopyge sp., Mustelus schimitti and Squatina guggenheim presented the highest percentage $(>80 \%)$ of mature individuals. Size-atmaturity was estimated for B. brachyurops, B. macloviana, Psammobatis lentiginosa, P. normani, P. rudis, Z. chilensis, S. bivius and Squalus acanthias (Table $3)$. For $B$. brachyurops and P. lentiginosa size-atmaturity was only estimated for males. Deviations from the 1:1 sex ratio were observed for B. magellanica, Z. chilensis, P. normani, P. rudis, Discopyge sp., $S$. acanthias, S. bivius and G. galeus (Table 1). $Z$. chilensis and $S$. acanthias presented a marked sexual segregation, with males more frequent in the surveys (Table 1). Regarding size variations with depth, the only species that presented significant differences were $B$. magellanica and $Z$. chilensis (Table 5). The largest individuals of $B$. magellanica were observed in the depth range of 100-109 $\mathrm{m}$, and the largest individuals of $Z$. chilensis were observed in the depth ranges of 60-69 and 70-79 $\mathrm{m}$ (Table 5).

\section{DISCUSSION}

Elasmobranchs currently represent one of the most threatened groups of all marine species due to the increasing fishing effort and, consequently, the overfishing of their populations (Stevens et al. 2000). Concern about the current status of elasmobranch populations has increased among researchers, and several studies have been conducted to address this topic (IUCN 2003). In Argentina, studies on elasmobranchs have been neglected in the past, and most research efforts have been directed to assess bony-fishes due to their economic importance. At present, this situation is changing with the creation of a national plan of action for conservation and management of elasmobranchs (Wöhler et al. 2011). Studies have been conducted on several elasmobranch species to rectify the lack of basic biological knowledge (Ruocco et al. 2006, Perez Comesaña et al. 2011, Scenna 2011). However, the information available so far is not sufficient to develop adequate management actions. A major problem in Argentina's fisheries is the scarce information available regarding both species biology and the specific composition of the elasmobranchs affected. Several species of elasmobranchs are discarded at sea; thus, they are not recorded in fishing 
Table 3. Biological information for elasmobranchs captured on the Argentine shelf, showing size-at-maturity (TL50\%), smallest mature (SM) and largest immature (LI) individual males (M) and females (F), total length (TL) and size range in parentheses. Letters ' $a$ ' and ' $b$ ' are the parameters of the logit function used to estimate TL50\%. FO: frequency of occurence. Dash: no data

\begin{tabular}{|c|c|c|c|c|c|c|}
\hline Species & $\begin{array}{l}\text { TL50\% } \\
(\mathrm{cm})\end{array}$ & SM-LI & $a / b$ & $\begin{array}{c}\mathrm{TL} \\
(\mathrm{cm})\end{array}$ & $\begin{array}{c}\% \text { Mature } \\
\text { individuals }\end{array}$ & $\begin{array}{l}\mathrm{FO} \\
(\%)\end{array}$ \\
\hline Amblyraja doellojuradoi & $\begin{array}{l}\mathrm{F}:- \\
\mathrm{M}:-\end{array}$ & $\begin{array}{l}\text { F: - } \\
\text { M: - }\end{array}$ & $\begin{array}{l}\text { F: - } \\
\text { M: - }\end{array}$ & $46.5(42-51)$ & $\begin{array}{l}\text { F: } 50 \\
\text { M: } 0\end{array}$ & 3 \\
\hline Atlantoraja cyclophora & $\begin{array}{l}\mathrm{F}:- \\
\mathrm{M}:-\end{array}$ & $\begin{array}{l}\mathrm{F}:- \\
\mathrm{M}:-\end{array}$ & $\begin{array}{l}\mathrm{F}:- \\
\mathrm{M}:-\end{array}$ & $51.5(42-61)$ & $\begin{array}{l}F: 20 \\
M: 0\end{array}$ & 3 \\
\hline Bathyraja albomaculata & $\begin{array}{l}\mathrm{F}:- \\
\mathrm{M}:-\end{array}$ & $\begin{array}{l}\mathrm{F}:- \\
\mathrm{M}:-\end{array}$ & $\begin{array}{l}\mathrm{F}:- \\
\mathrm{M}:-\end{array}$ & $69.5(51-88)$ & $\begin{array}{l}\text { F: } 66 \\
\text { M: } 85\end{array}$ & 14 \\
\hline Bathyraja brachyurops & $\begin{array}{c}\text { F: - } \\
\text { M: } 71.3\end{array}$ & $\begin{array}{c}\text { F: } 69-71.3 \\
\text { M: } 63.5-71.4\end{array}$ & $\begin{array}{c}\mathrm{F}:- \\
\mathrm{M}:-290.25 / 4.07\end{array}$ & $68(36-83)$ & $\begin{array}{l}\text { F: } 40 \\
\text { M: } 49\end{array}$ & 30 \\
\hline Bathyraja macloviana & $\begin{array}{l}\text { F: } 57.8 \\
\text { M: } 54.3\end{array}$ & $\begin{array}{l}\text { F: } 33.5-57 \\
\text { M: } 57-58\end{array}$ & $\begin{array}{c}F:-310.07 / 5.36 \\
M:-302.06 / 5.56\end{array}$ & $48.5(32-65)$ & $\begin{array}{l}\text { F: } 50 \\
\text { M: } 64\end{array}$ & 10 \\
\hline Bathyraja magellanica & $\begin{array}{l}\text { F: - } \\
\text { M: - }\end{array}$ & $\begin{array}{l}\text { F: - } \\
\text { M: - }\end{array}$ & $\begin{array}{l}\text { F: - } \\
\text { M: - }\end{array}$ & $54(38-70)$ & $\begin{array}{l}\text { F: } 70 \\
\text { M: } 75\end{array}$ & 17 \\
\hline Bathyraja multispinnis & $\begin{array}{l}\mathrm{F}:- \\
\mathrm{M}:-\end{array}$ & $\begin{array}{l}\mathrm{F}:- \\
\mathrm{M}:-\end{array}$ & $\begin{array}{l}\mathrm{F}:- \\
\mathrm{M}:-\end{array}$ & $86.5(54-119)$ & $\begin{array}{l}\text { F: } 75 \\
\text { M: } 66\end{array}$ & 10 \\
\hline Bathyraja scaphiops & $\begin{array}{l}\mathrm{F}:- \\
\mathrm{M}:-\end{array}$ & $\begin{array}{l}\mathrm{F}:- \\
\mathrm{M}:-\end{array}$ & $\begin{array}{l}\mathrm{F}:- \\
\mathrm{M}:-\end{array}$ & $46.5(41-73)$ & $\begin{array}{l}\mathrm{F}: 80 \\
\mathrm{M}:-\end{array}$ & 3 \\
\hline Discopyge sp. & $\begin{array}{l}\mathrm{F}:- \\
\mathrm{M}:-\end{array}$ & $\begin{array}{l}\mathrm{F}:- \\
\mathrm{M}:-\end{array}$ & $\begin{array}{l}\mathrm{F}:- \\
\mathrm{M}:-\end{array}$ & $36(25-47)$ & $\begin{array}{l}F: 82 \\
\text { M: } 89\end{array}$ & 7 \\
\hline Galeorhinus galeus & $\begin{array}{l}\mathrm{F}:- \\
\mathrm{M}:-\end{array}$ & $\begin{array}{l}\mathrm{F}:- \\
\mathrm{M}:-\end{array}$ & $\begin{array}{l}\mathrm{F}:- \\
\mathrm{M}:-\end{array}$ & $104(70-120)$ & $\begin{array}{l}F: 20 \\
M: 16\end{array}$ & 5 \\
\hline Mustelus schmitti & $\begin{array}{l}\mathrm{F}:- \\
\mathrm{M}:-\end{array}$ & $\begin{array}{l}\mathrm{F}:- \\
\mathrm{M}:-\end{array}$ & $\begin{array}{l}\text { F: - } \\
\text { M: - }\end{array}$ & $74(59-89)$ & $\begin{array}{l}\text { F: } 100 \\
\text { M: } 93\end{array}$ & 9 \\
\hline Myliobatis sp. & $\begin{array}{l}F:- \\
M:-\end{array}$ & $\begin{array}{l}F:- \\
M:-\end{array}$ & $\begin{array}{l}\text { F: - } \\
\text { M: - }\end{array}$ & 120 & $\begin{array}{l}\text { F: } 100 \\
\text { M: - }\end{array}$ & 2 \\
\hline Psammobatis lentiginosa & $\begin{array}{c}\text { F: }- \\
\text { M: } 41.1\end{array}$ & $\begin{array}{c}\text { F: }- \\
\text { M: } 42-42\end{array}$ & $\begin{array}{c}\mathrm{F}:- \\
\mathrm{M}:-200.25 / 4.87\end{array}$ & $37(26-48)$ & $\begin{array}{l}\text { F: } 62 \\
\text { M: } 86\end{array}$ & 16 \\
\hline Psammobatis normani & $\begin{array}{l}\text { F: } 42.9 \\
\text { M: } 48.3\end{array}$ & $\begin{array}{c}\text { F: } 41.4-55 \\
\text { M: } 42.1-52.8\end{array}$ & $\begin{array}{l}F:-200.36 / 4.67 \\
M:-210.3 / 4.35\end{array}$ & $41(25-57)$ & $\begin{array}{l}\mathrm{F}: 70 \\
\mathrm{M}: 55\end{array}$ & 80 \\
\hline Psammobatis rudis & $\begin{array}{c}\text { F: } 41 \\
\text { M: } 41.46\end{array}$ & $\begin{array}{l}\mathrm{F}:- \\
\mathrm{M}:-\end{array}$ & $\begin{array}{c}\mathrm{F}:-212.25 / 5.17 \\
\mathrm{M}:-210.24 / 5.07\end{array}$ & $37(23-51)$ & $\begin{array}{l}F: 42 \\
M: 54\end{array}$ & 70 \\
\hline Schroederichthys bivius & $\begin{array}{c}\text { F: } 55 \\
\text { M: } 64.9\end{array}$ & $\begin{array}{l}\text { F: } 65.8-71 \\
\text { M: } 66-66\end{array}$ & $\begin{array}{c}F:-300.06 / 5.45 \\
M:-300.07 / 4.62\end{array}$ & $61.5(40-83)$ & $\begin{array}{l}\text { F: } 0.05 \\
\text { M: } 94\end{array}$ & 66 \\
\hline Squalus acanthias & $\begin{array}{l}F: 72.85 \\
M: 66.1\end{array}$ & $\begin{array}{l}\text { F: } 58-67 \\
\text { M: } 53-65\end{array}$ & $\begin{array}{c}F:-289.24 / 3.97 \\
M:-269.24 / 4.07\end{array}$ & $65(35-95)$ & $\begin{array}{l}\text { F: } 45 \\
\text { M: } 70\end{array}$ & 90 \\
\hline Squalus cf. mitsukurii & $\begin{array}{l}\mathrm{F}:- \\
\mathrm{M}:-\end{array}$ & $\begin{array}{l}\mathrm{F}:- \\
\mathrm{M}:-\end{array}$ & $\begin{array}{l}\mathrm{F}:- \\
\mathrm{M}:-\end{array}$ & $64(52-76)$ & $\begin{array}{l}F: 68 \\
M: 84\end{array}$ & 15 \\
\hline Squatina guggenheim & $\begin{array}{l}\mathrm{F}:- \\
\mathrm{M}:-\end{array}$ & $\begin{array}{l}\mathrm{F}:- \\
\mathrm{M}:-\end{array}$ & $\begin{array}{l}\mathrm{F}:- \\
\mathrm{M}:-\end{array}$ & $35(28-40)$ & $\begin{array}{l}\text { F: } 100 \\
\text { M: } 100\end{array}$ & 2 \\
\hline Zearaja chilensis & $\begin{array}{l}\text { F: } 92.5 \\
\text { M: } 74.4\end{array}$ & $\begin{array}{l}\text { F: } 83-85 \\
\text { M: } 72-79\end{array}$ & $\begin{array}{c}F:-330.26 / 3.57 \\
M:-310.25 / 4.17\end{array}$ & $64.5(21-108)$ & $\begin{array}{l}\text { F: } 12 \\
\text { M: } 29\end{array}$ & 100 \\
\hline
\end{tabular}

statistics, while landed species are often recorded under main items such as 'sharks' and 'skates' (Perez Comesaña et al. 2011, Sánchez et al. 2011). The bottom-trawl fishery that targets Merluccisus hubbsi on the Argentine shelf is not an exception, and the low reliability of the landing statistics of elasmobranchs is a major problem. The present study provides important information about the elasmobranch species affected by this fishery. During the studied period, 20 species of elasmobranchs were registered. Out of the 40 species of sharks described on the Argentine shelf (Menni \& Lucifora 2007), only 6 were captured. Regarding the order Rajiformes, 12 species were captured of the 24 described (Menni \& Lucifora 2007). Also, 1 species of the order Myliobatiformes and 1 of the order Torpediniformes were identified in catches. 


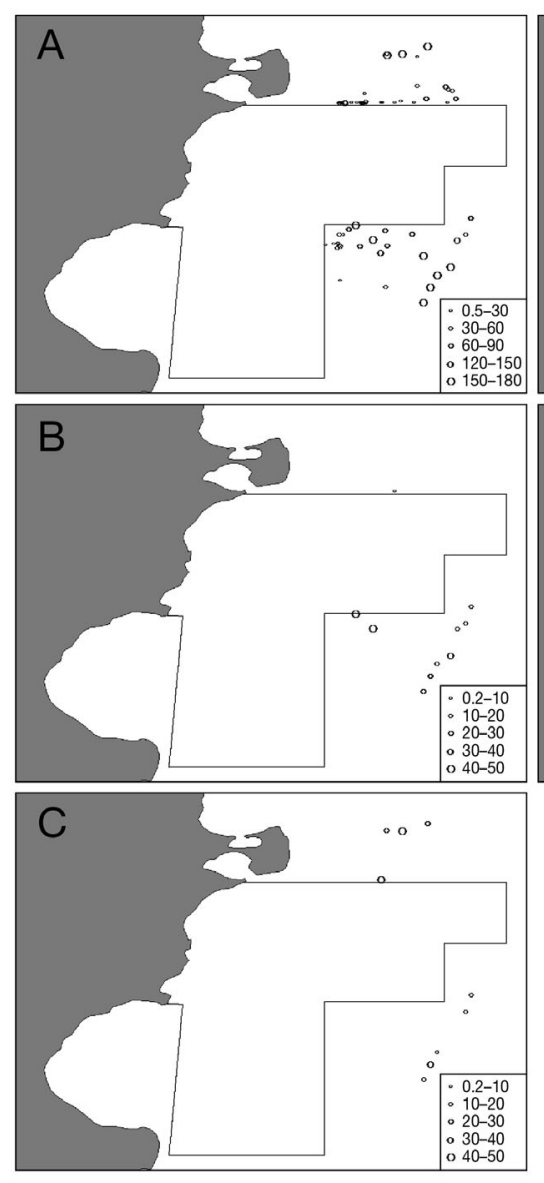

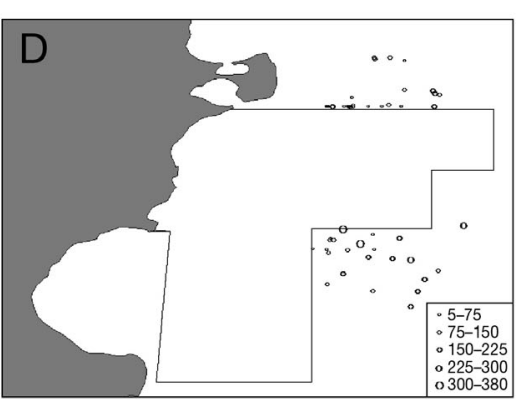

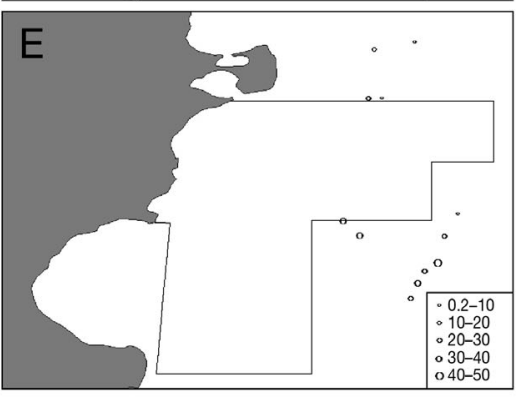

Fig. 2. Relative abundance (ind. $\mathrm{km}^{-2}$ ) on the Argentine shelf of (A) Zearaja chilensis, (B) Psammobatis normani, (C) Psammobatis rudis, (D) Squalus acanthias and (E) Schroederichthys bivius. The area enclosed by the grey line represents the permanent closure for the Merluccius hubbsi fishery logical information on them is still scarce (Perez Comesaña et al. 2011). For $Z$. chilensis, the size range observed was similar to that reported by García de la Rosa (1998) for the same region. Estimations of the size-at-maturity $(92 \mathrm{~cm}$ for females and $76 \mathrm{~cm}$ for males) are similar to previous estimations (91 cm for females and $77 \mathrm{~cm}$ for males) (Perez Comesaña et al. 2011). Recently, the existence of a new species, Dipturus argentinensis, similar to $Z$. chilensis has been proposed using morphological and molecular evidence (Diaz de Astarloa et al. 2008). Considering this, it is possible that some individual $D$. argentinensis were present in our samples; thus, although estimations given in the present study are reliable, they should be verified. For $S$. acanthias, the size range observed was also similar to that reported previously (Menni et al. 1981, García de la Rosa 1998, Gosztonyi \& Kuba 1998, Di Giácomo et al. 2009), but the size-at-maturity was not estimated. Our estimations are a novel contribution to the knowledge of the species on the Argentine

Zearaja chilensis and Squalus acanthias presented the highest values of relative abundance and were present in all surveys. It is well known that both species are the most abundant elasmobranchs in Argentine waters (Cousseau et al. 2000). Despite this, bioshelf. However, this parameter has been estimated in other regions of the world, and the results show that the size-at-maturity of $S$. acanthias is highly variable depending on the region considered. Estimations vary from $70 \mathrm{~cm}$ (North Sea; Sosinski 1978) to $109 \mathrm{~cm}$ (NE

Table 4. Length-to-weight relationship parameters for some elasmobranch species (ANCOVA, $p>0.05$, df $=2$ ). The 95\% confidence intervals of the slope and intercept of the regression are shown in parentheses. The hypothesis of isometric growth was tested using a Student's $t$-test

\begin{tabular}{|c|c|c|c|c|c|c|c|}
\hline Species & $\begin{array}{l}\text { Size range }(\mathrm{cm}) \\
\quad(\min -\max )\end{array}$ & Slope & Intercept & $\mathrm{R}^{2}$ & Type & $\begin{array}{l}\text { Growth } \\
\text { p-value }\end{array}$ & $\mathrm{df}$ \\
\hline Bathyraja albomaculata & $51-88$ & $3.05(2.98 ; 3.10)$ & $-4.99(-5.29 ;-4.68)$ & 0.948 & Isometric & $>0.05$ & 18 \\
\hline Bathyraja brachyurops & $36-85$ & $3.25(3.18 ; 3.31)$ & $-5.91(-6.23 ;-5.58)$ & 0.968 & Isometric & $>0.05$ & 78 \\
\hline Bathyraja macloviana & $32-65$ & $3.05(2.90 ; 3.18)$ & $-5.05(-5.70 ;-4.29)$ & 0.987 & Isometric & $>0.05$ & 31 \\
\hline Bathyraja maguellanica & $38-65$ & $3.04(2.89 ; 3.17)$ & $-5.15(-5.58 ;-4.71)$ & 0.991 & Isometric & $>0.05$ & 29 \\
\hline Bathyraja multispinnis & $54-119$ & $3.08(2.50 ; 3.66)$ & $-5.38(-5.69 ;-5.07)$ & 0.973 & Isometric & $>0.05$ & 13 \\
\hline Discopyge sp. & $25-47$ & $3.21(3.14 ; 3.27)$ & $-5.13(-5.45 ;-4.81)$ & 0.930 & Allometric & $<0.05$ & 47 \\
\hline Galeorhinus galeus & $68-146$ & $3.22(2.70 ; 3.74)$ & $-6.57(-6.89 ;-6.24)$ & 0.990 & Allometric & $<0.05$ & 19 \\
\hline Mustelus schmitti & $59-88$ & $2.61(2.56 ; 2.66)$ & $-3.98(-5.24 ;-2.72)$ & 0.897 & Allometric & $<0.05$ & 29 \\
\hline Psammobatis lentiginosa & $26-48$ & $2.988(2.92 ; 3.04)$ & $-4.46(-4.75 ;-4.15)$ & 0.937 & Isometric & $>0.05$ & 43 \\
\hline Psammobatis normani & $23-56$ & $2.79(2.60 ; 2.97)$ & $-4.09(-5.36 ;-2.80)$ & 0.860 & Allometric & $<0.05$ & 653 \\
\hline Psammobatis rudis & $22-52$ & $3.03(2.60 ; 3.34)$ & $-5.04(-5.33 ;-4.73)$ & 0.929 & Isometric & $>0.05$ & 272 \\
\hline Schroederichthys bivius & $45-79$ & $2.68(2.63 ; 2.73)$ & $-4.61(-3.66 ;-5.56)$ & 0.924 & Allometric & $<0.05$ & 280 \\
\hline Squalus acanthias & $34-97$ & $3.16(3.09 ; 3.22)$ & $-6.21(-6.53 ;-5.89)$ & 0.959 & Allometric & $<0.05$ & 1791 \\
\hline Zearaja chilensis & $15-114$ & $3.06(2.99 ; 3.12)$ & $-6.12(-7.01 ;-5.42)$ & 0.977 & Isometric & $>0.05$ & 1447 \\
\hline
\end{tabular}




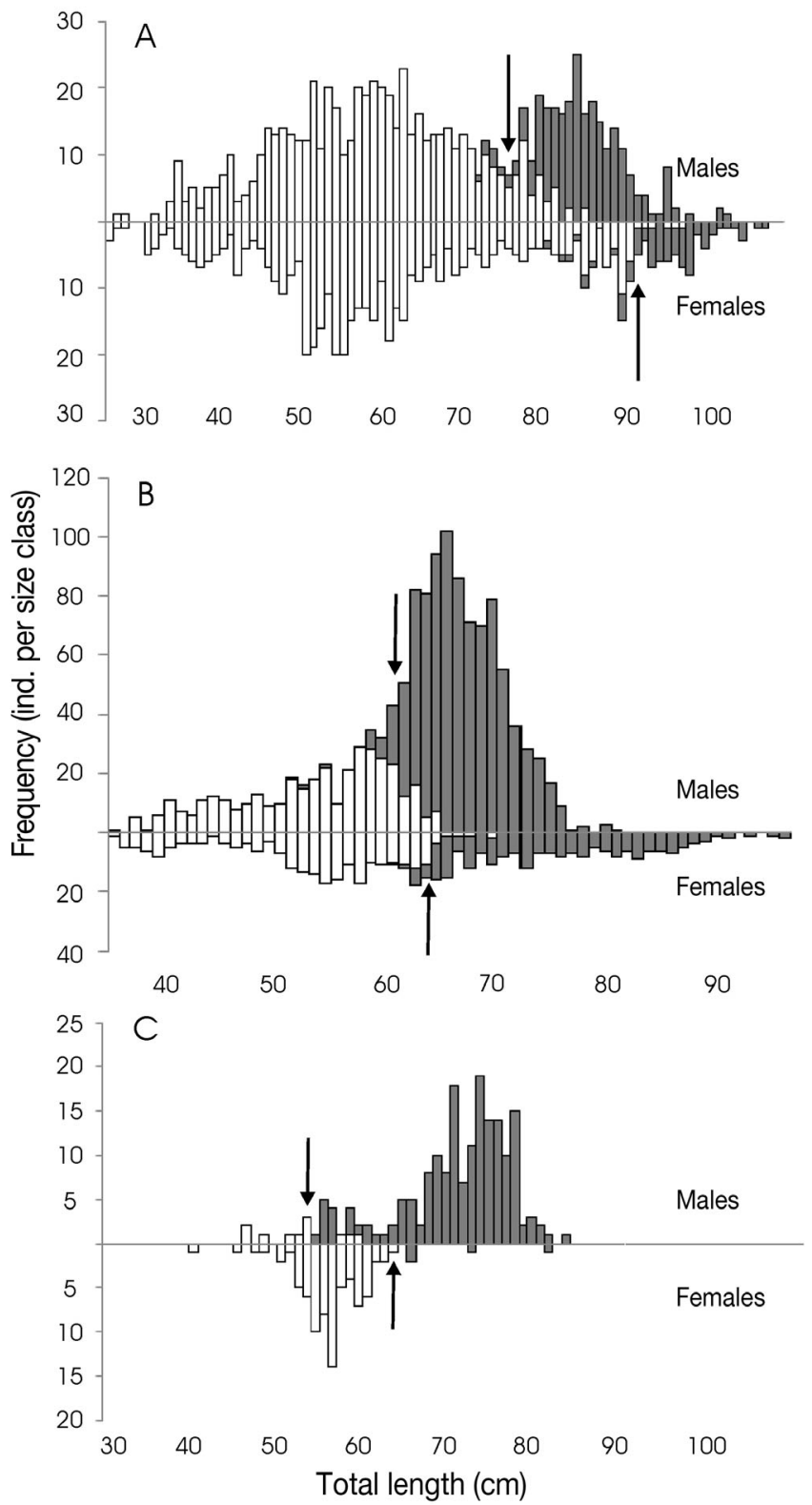

Pacific; Ketchen 1972) in females and from $59 \mathrm{~cm}$ (NE Atlantic; Hickling 1930) to $82 \mathrm{~cm}$ (SE Black Sea; Avsar 2001) in males. Our estimations are within the range of values published for the species.

The genus Bathyraja is represented by 11 species in the SW Atlantic, 8 of them are endemic to the Argentine continental shelf (Menni \& Stehmann 2000, Díaz de Astarloa \& Mabragaña 2004), and, in this study, 6 species were registered. Bathyraja albomaculata, B. magellanica, B. scaphiops and B. multispinis showed low values of relative abundance $\left(<5\right.$ ind $\left.\mathrm{km}^{-2}\right)$ and a low frequency of occurrence $(<20 \%)$. The low relative abundance and frequency in the studied area could be attributed to the fact that
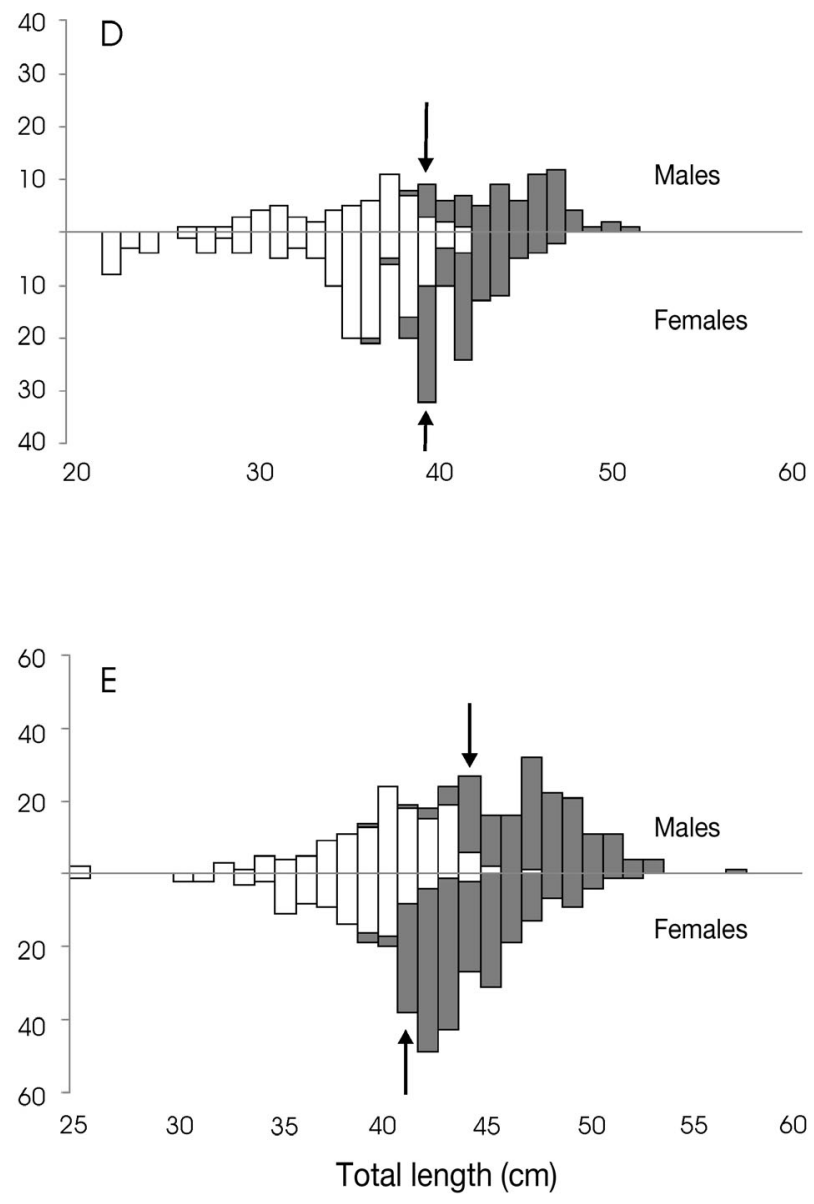

Fig. 3. Size-frequency distributions of males and females of (A) Zearaja chilensis, (B) Squalus acanthias, (C) Schroederichthys bivius, (D) Psammobatis normani and (E) Psammobatis rudis, captured on the Argentine shelf. White bars: immature individuals; grey bars: mature individuals; black arrows: the size-at-maturity estimated for each sex

these species are more abundant south of $45^{\circ}$ (Menni \& Stehmann 2000, Scenna 2011). Bathyraja macloviana and $B$. brachyurops were more abundant and frequent in the studied area, which is consistent with previous observations for the region (Scenna 2011). For $B$. brachyurops, the size-at-maturity estimated for males $(67.86 \mathrm{~cm})$ was similar to sizes previously reported $(66.4 \mathrm{~cm})$ (Perez Comesaña et al. 2011, Scenna 2011). In the case of the female, the size-atmaturity was not estimated due to the restricted sample size composition. However, based on the sizes of the smallest mature and the largest immature individuals observed, it is likely that the size-at-maturity is close to the previous estimation of $73.4 \mathrm{~cm}$ (Perez 
Table 5. Mean size $(\mathrm{cm})$ of individuals in each depth range. Mean sizes that differed significantly on each depth range are marked with asterisk

\begin{tabular}{|c|c|c|c|c|c|c|c|}
\hline \multirow{2}{*}{ Species } & \multicolumn{7}{|c|}{ Depth } \\
\hline & $60-69$ & $70-79$ & $80-89$ & $90-99$ & $100-109$ & $110-119$ & $120-129$ \\
\hline Bathyraja albomaculata & & 65 & & & 67.2 & 69.7 & \\
\hline Bathyraja brachyurops & & & 67.5 & 71.4 & 62.5 & 61.5 & 72.2 \\
\hline Bathyraja macloviana & & & & & 47.2 & 52.4 & \\
\hline Bathyraja magellanica & 57.6 & 52.5 & & & $72.7^{*}$ & 57.6 & 52.5 \\
\hline Bathyraja multispinnis & & & & & 69.5 & 71.5 & \\
\hline Discopyge sp. & 36.6 & 39.7 & & & & & \\
\hline Galeorhinus galeus & & 135.2 & 134.5 & 120 & & 134 & \\
\hline Mustelus schmitti & & 75.3 & 72.7 & & & & \\
\hline Psammobatis lentiginosa & 35.2 & & & & 31.9 & 38.7 & 40.3 \\
\hline Psammobatis normani & & 41 & 51.2 & 42.3 & 41.4 & 45.1 & 41 \\
\hline Psammobatis rudis & 32.5 & 32.2 & & & 44.1 & 32.5 & 32.2 \\
\hline Schroederichthys bivius & 73.5 & 70.1 & 74.1 & 70.8 & 73.1 & 68.2 & \\
\hline Squalus acanthias & 74.2 & 65.7 & 60.3 & 64.2 & 61.1 & 59.2 & 66.5 \\
\hline Squalus cf. mitsukurii & & 63.2 & 58.4 & 68.9 & 67.3 & 63.2 & 58.4 \\
\hline Zearaja chilensis & $80^{*}$ & $83.45^{*}$ & 59.9 & 58.3 & 58.7 & 56.5 & 55.8 \\
\hline
\end{tabular}

Comesaña et al. 2011, Scenna 2011). These results should be considered with caution since there is a possibility that some of the individuals may have belonged to $B$. cousseauae. This species has recently been described by Díaz de Astarloa \& Mabragaña (2004) and was not present in the species keys used. For B. macloviana, the estimated size-at-maturity for males in this study $(36.5 \mathrm{~cm})$ was significantly smaller than that reported in previous studies $(53 \mathrm{~cm})$ (Perez Comesaña et al. 2011, Scenna 2011). Due to the small number of males analyzed, this estimation should be carefully considered. In the case of females, estimations obtained in the present study $(57.4 \mathrm{~cm})$ were similar to those in previous studies $(54 \mathrm{~cm})$ (Perez Comesaña et al. 2011, Scenna 2011).

Skates belonging to the genus Psammobatis are small-sized individuals endemic to the southwestern Atlantic Ocean (Cousseau et al. 2000, Mabragaña 2007, Mabragaña \& Giberto 2007). In the present study, 3 species were captured of the 7 described for the Argentine shelf (Menni \& Stehmann 2000). Psammobatis normani and $P$. rudis were the most abundant and frequent species in the surveys. It is known that both species are the most common species of this genus on the Argentine shelf (Mabragaña 2007). For $P$. normani, the size range observed $(25$ to $57 \mathrm{~cm}$ ) was similar to that reported by Mabragaña \& Cousseau (2004) $(24$ to $58 \mathrm{~cm})$. The size-at-maturity estimated for males in this study $(44 \mathrm{~cm})$ was similar to the size reported by Mabragaña \& Cousseau (2004) $(44.3 \mathrm{~cm})$. In contrast, the size-at-maturity estimated for females $(41.5 \mathrm{~cm})$ was greater than that reported by Mabragaña \& Cousseau (2004) $(40.3 \mathrm{~cm})$. For P. rudis, smaller individuals $(23 \mathrm{~cm})$ were recorded in the area than those reported by Mabragaña \& Cousseau $(2004)(26 \mathrm{~cm})$. The maturity size estimated for both sexes $(40 \mathrm{~cm})$ was smaller than previous estimations (42.8 $\mathrm{cm}$ for females and $41.4 \mathrm{~cm}$ for males) (Mabragaña \& Cousseau, 2004). P. lentiginosa was the least frequent species of the genus in our samplings with a $\% \mathrm{FO}$ of $16 \%$. A similar value of occurrence was reported by Mabragaña (2007) in the area. The sizeat-maturity estimated for males $(41.6 \mathrm{~cm})$ was notably higher than that estimated by Mabragaña (2007) $(31.3 \mathrm{~cm})$. For females, the low sample size did not allow an estimation of the size-at-maturity, but it would be expected to find a similar difference compared to Mabragaña's (2007) estimation.

Schroederichthys bivius is commonly found along the continental shelf off Argentina, but few studies on this species have been conducted (Menni et al. 1979, Sánchez et al. 2009). Perez Comesaña et al. (2011) pointed out the lack of basic biological information about this species. In this sense, our results complement the existing information by proving the first estimations of the maturity size, sex proportions, size-frequency distribution and proportion of mature individuals for the species on the continental shelf. This species was frequently captured in our study ( $>60 \%$ of the tows analyzed), and the abundance was highly variable, with the lowest values in austral summer. Sánchez et al. (2009) found lower values of $\% \mathrm{FO}$ for $\mathrm{S}$. bivius $\left(43.7 \%\right.$ north of $45^{\circ} \mathrm{S}$ and $56 \%$ south of $46^{\circ} \mathrm{S}$ ) on the Argentine shelf. Regarding the size of individuals, males reached greater values than females. This marked dimorphism in the maximum size is common in sharks belonging to Scyliorhinidae (Flammang et al. 2008). 
The sharks Squalus mitsukurii, Galeorhinus galeus and Mustelus schmitti were less frequent in the samplings ( $<15 \%$ of the tows analyzed). However, G. galeus and M. schmitti presented a marked pattern of seasonal aggregation, reaching values $>27$ ind. $\mathrm{km}^{-2}$ in March 2002 and September 2001, respectively. This aggregation pattern is commonly found in several shark species (Jacoby et al. 2012), but no records for G. galeus and M. schmitti aggregations on the continental shelf have been published before.

The species Atlantoraja cyclophora, A. doellojuradoi, Discopyge sp., Myliobatis sp. and Squatina guggenheim were captured occasionally with low relative abundance $\left(<5\right.$ ind. $\left.\mathrm{km}^{-2}\right)$, indicating that their presence on the northern Patagonian shelf is not frequent. The first 2 species are more abundant in waters north of $41^{\circ} \mathrm{S}$, while the low presence of the last 3 species may be a consequence of their coastal distribution (Vooren \& Da Silva 1991, Cervigón et al. 1992, Cousseau et al. 2000, Menni et al. 2010).

The relationship between body length and weight is of great importance in fishery biology (Gulland 1983, Sparre 1991). Biomass estimates obtained from widely used analytical models, such as virtual population analysis, require the mean weight calculation of individuals per age or length class through the length-to-weight relationship. Therefore, obtaining accurate parameter estimations of the length-toweight relationship is an important factor in the assessment of fish stocks. In this paper, estimations were reported for 14 different species of elasmobranchs that inhabit the Argentine shelf. There were no significant differences found in the length-toweight relationships between both sexes for any of the species studied. This is a common pattern in several elasmobranch species (Kohler et al. 1996, Lucifora et al. 1999, Ruocco et al. 2006, Mabragaña 2007, Scenna 2011). Allometric growth type was observed in the length-to-weight relationships of 6 species. The variation between the estimated allometric coefficient and the theoretical value ( 3 in the case of a linear-volume relationship) means that individuals' gain/loss in average weight occurred at a different rate than expected. This value can be affected by several factors, including the amount of stomach contents, the stage of maturity, the liver weight and the general condition of the individuals (Frota et al. 2004). Thus, these variables should be considered in further estimations of length-to-weight relationships.

Several cases of size segregation in elasmobranchs have been reported in Argentine waters, mainly in coastal regions (Di Giácomo et al. 2009, Perier et al. 2011). It is known that shallow waters are used by several species of elasmobranchs as reproductive and nursery grounds, because these areas provide shelter and food availability for offspring (Heupel et al. 2007). Therefore, it is expected to find a heavy concentration of large individuals (adults) during reproductive periods and heavy concentration of small individuals (offspring) during breeding periods. In this study, the only species that presented significant differences in size in the different depth strata were Bathyraja magellanica and Zearaja chilensis. Both species presented the same pattern of larger sizes in shallower waters. The rest of the species presented no significant differences in the mean size of individuals in the different depth strata, probably due to the limited depth range considered.

A common ecological trait of many elasmobranch species is their tendency to concentrate in groups of many individuals in particular spatio-temporal patterns (Jacoby et al. 2012). This increases their susceptibility to being overexploited by fisheries that operate in those locations. On the Argentine shelf, few species presented a marked aggregation of individuals. The sharks Galeorhinus galeus, Mustelus schmitti and Squalus acanthias presented the highest abundances in summer, in spring and in winter, respectively. Zearaja chilensis presented the highest values of abundance in autumn and winter. The lack of knowledge concerning the population abundance of those species limits the analysis of the impact caused by fishing.

Our results have shown that most of the individuals affected by the bottom-trawl fishery were mature. This means that intense fishing pressure may lead to a reduction in recruitment having a negative effect on the population, since elasmobranchs are characterized by a direct relationship between recruitment and stock size (Holden 1977). However, for Schroederichthys bivius and Zearaja chilensis, most individuals captured $(>70 \%)$ were immature. This situation is alarming since fishing mortality affects individuals that never spawned, and this will have a negative impact on both species (particularly in $Z$. chilenses, due to its high frequency and abundance). As precautionary measure, it will be necessary to alter the current fishery situation by reducing the fisheryassociated mortality of elasmobranchs (i.e. temporal or spatial closures, use of specific repellent devices) in order to minimize the negative impacts on populations. Recently, Chiaramonte et al. (2011) showed that several elasmobranch species present high survival rates (>75\%) after being released back into sea. Therefore, this practice would represent a simple way of reducing elasmobranch mortality and could be implemented in fishing activities. 
Fishery management is evolving towards a more holistic approach (i.e. ecosystem-based management) to ensure the sustainability of resources (Zhou et al. 2010). This insight requires basic biological information of the species affected by the fishery (i.e. elasmobranchs). In Argentina, management of the common hake Merluccisus hubbsi bottom-trawl fishery has been conducted on a monospecific basis, due to the lack of biological knowledge regarding bycatch (Bezzi et al. 1994). The paucity of information on the population status of elasmobranchs (i.e. population sizes, fishing mortality) has been a major obstruction to comparisons with our results in an effort to determine the effect of the fishery over time. However, the data generated in the present study can be used as a basis for comparing the current species composition situation and the relative abundance of elasmobranch by-catch in the bottom-trawl fishery of northern Patagonia. Considering that fishing effort has not been reduced since 2003 and that a reduction is unlikely to be achieved in the near future in this fishery, continuous monitoring is necessary to obtain more information on the long-term temporal trends on elasmobranch populations. It is worth mentioning that, despite the call for continuous monitoring, no studies have been conducted since 2003 on the effects of this fishery on elasmobranch species composition.

Acknowledgements. The authors are indebted to many people and institutions that collaborated with this research. We thank Centro Nacional Patagónico (National Research Council of Argentina) and the University of Patagonia for the institutional and logistical support given throughout this study. Financial support was provided by PICT 01-04025 Agencia Nacional de Promoción Científica y Tecnológica (1998 to 2002), Plan de Manejo Integrado de la Zona Costera Patagónica (GEF/PNUD) (1993 to 1996), Agencia Española de Cooperación Internacional (1996 to 1998), Cetacean Specialist Group, IUCN (1999) and Cetacean Society International (1999). We also thank fishermen officers, officers of the Fishery Government Agencies of Chubut Province and the National Coast Guard. We thank ALPESCA S.A. and HARENGUS S.A. for allowing our survey on board their trawling fishing vessels. We are also grateful to the vessel crews, Pablo Marioti and Alejandro Buren for their help on board. We especially thank the reviewers who have contributed significantly to the improvement of this manuscript.

\section{LITERATURE CITED}

Aubone A, Bezzi SI, Cañete G, Castrucci R and others (2004) Evaluación y sugerencias de manejo del recurso merluza (Merluccius hubbsi). La situación hasta 1999. In: Sánchez RP, Bezzi SI (eds) El Mar Argentino y sus recursos pesqueros, Tomo 4. Los peces marinos de interés pesquero.
Caracterización biológica y evaluación del estado de explotación. INIDEP, Mar del Plata, p 207-235

Avsar D (2001) Age, growth, reproduction and feeding of the spurdog (Squalus acanthias Linnaeus, 1758) in the southeastern Black Sea. Estuar Coast Shelf Sci 52:269-278

Bezzi S, Cañete G, Pérez M, Renzi M, Lassen H (1994) Report of the INIDEP working group on assessment of hake (Merluccius hubbsi) north of $48^{\circ} \mathrm{S}$ (Southwest Atlantic Ocean). INIDEP Scientific Report 3, INIDEP, Mar del Plata

Cervigón F, Cipriani R, Fischer W, Garibaldi L and others (1992) Fichas FAO de identificación de peces para los fines de la pesca. Guía de campo de las especies comerciales marinas de aguas salobres de la costa septentrional de Sur América 513. FAO, Rome

Chiaramonte GE (1998) Shark fisheries in Argentina. Mar Freshw Res 49:601-609

Chiaramonte GE, Tamini LL, Perez Comesaña JE (2011) Evaluación de la supervivencia de elasmobranquios capturados por arrastreros de fondo. In: Wöhler OC, Cedrola P, Cousseau MB (eds) Contribuciones sobre biología, pesca y comercialización de tiburones en la Argentina. Aportes para la elaboración del plan de acción nacional. Consejo federal pesquero, Buenos Aires, p 217-222

Colonello JH, Christiansen HE, Macchi GJ (2011) Escala de madurez sexual para peces cartilaginosos de la Plataforma Continental Argentina. In: Wohler OC, Cedrola P, Cousseau MB (eds) Contribuciones sobre biología, pesca y comercialización de tiburones en la Argentina. Aportes para la elaboración del Plan de Acción nacional. Consejo federal pesquero, Buenos Aires, p 115-128

Cortés E (2000) Life history patterns and correlations in sharks. Rev Fish Sci 8:299-344

Cousseau MB, Figueroa DE, Díaz de Astarloa JM (2000) Clave de identificación de las rayas del litoral marítimo de Argentina y Uruguay (Chondrichthyes, Familia Rajidae). Publicaciones especiales, INIDEP, Mar del Plata

> Crespi-Abril AC, García NA, Crespo EA, Coscarella MA (2003) Consumption of marine mammals by broadnose sevengill shark Notorynchus cepedianus in the northern and central Patagonian shelf. Latin Am J Aquat Mamm 2: 101-107

Di Giácomo EE, Perier MR, Coller NM (2009) Reproduction of spiny dogfish Squalus acanthias in San Matías Gulf, Patagonia (Argentina). In: Gallucci VF, McFarlane GA, Bargmann GG (eds) Biology and management of dogfish sharks. American Fisheries Society, Bethesda, MD, p 209-215

Díaz de Astarloa JM, Mabragaña E (2004) Bathyraja cousseauae sp. n., a new softnose skate from the southwestern Atlantic (Rajiformes, Rajidae). Copeia 326-335

Diaz de Astarloa JM, Mabragaña E, Hanner R, Figueroa DE (2008) Morphological and molecular evidence for a new species of longnose skate (Rajiformes: Rajidae: Dipturus) from Argentinean waters based on DNA barcoding. Zootaxa 1921:35-46

Elías I, Rodríguez A, Amoroso R, Reyna MV (2005) Biological observations of the tope shark, Galeorhinus galeus, in the Northern Patagonian gulfs of Argentina. J Notrhwest Atl Fish Sci 35:261-265

- Flammang BE, Ebert DA, Cailliet GM (2008) Reproductive biology of deep-sea catsharks (Chondrichthyes: Scyliorhinidae) in the eastern North Pacific. Environ Biol Fishes 81:35-49

> Frisk MG, Miller TJ, Fogarty MJ (2001) Estimation and 
analysis of biological parameters in elasmobranch fishes: a comparative life history study. Can J Fish Aquat Sci 58: 969-981

Frota LO, Costa PAS, Braga AC (2004) Length-weight relationships of marine fishes from the central Brazilian coast. Naga 27:20-26

García de la Rosa SB (1998) Estudio de las interrelaciones tróficas de dos elasmobranquios del Mar Argentino, en relación con las variaciones espacio-temporales y ambientales Squalus acanthias (Squalidae) y Raja flavirostris (Rajidae). PhD dissertation, Universidad Nacional de Mar del Plata, Mar del Plata

Gosztonyi AE, Kuba L (1998) Presencia de Squalus mitsukurii y aspectos de su biología y la de Squalus acanthias (Chondrichthyes, Squalidae) en aguas argentinas en febrero y junio-julio de 1983. Pub Com Tec Frente Mar 17:49-60

Gulland JA (1983) Fish stock assessment: a manual of basic methods. Wiley, Chichester

> Heupel MR, Carlson JK, Simpfendorfer C (2007) Shark nursery areas: concepts, definition, characterization and assumptions. Mar Ecol Prog Ser 337:287-297

> Hickling CF (1930) A contribution towards the life-history of the spur-dog. J Mar Biol Assoc UK 16:529-576

Hoenig JM, Gruber SH (1990) Life-history patterns in the elasmobranchs: implications or fisheries management. In: Pratt HL Jr, Gruber SH, Taniuchi T (eds) Elasmobranchs as living resources: advances in the biology, ecology, systematics, and the status of fisheries. US Department of Commerce, NOAA Technical Report NMFS (National Marine Fisheries Service) 90, Washington, DC, p 1-16

Holden MJ (1977) Elasmobranch. In: Gulland JA (ed) Fish population dynamics. John Wiley \& Sons, London, p $187-216$

IUCN (2003) The threatened states of sharks and related species. www.flmnh.ufl.edu/fish/organizations/SSG/SSG Default.htm (accessed September 2003)

> Jacoby DMP, Croft DP, Sims DW (2012) Social behaviour in sharks and rays: analysis, patterns and implications for conservation. Fish Fish 13:399-417

Kelleher K (2005) Discards in the world's marine fisheries. An update. Fish Tech Paper 470, FAO, Rome

Ketchen KS (1972) Size at maturity, fecundity, and embryonic growth of the spiny dogfish (Squalus acanthias L.) in British Columbia waters. J Fish Res Board Can 29: 1717-1723

Koen Alonso M, Crespo EA, García NA, Pedraza SN, Mariotti PA, Berón Vera B, Mora NJ (2001) Food habits of Dipturus chilensis (Pisces: Rajidae) off Patagonia, Argentina. ICES J Mar Sci 58:288-297

Kohler NE, Casey JG, Turner PA (1996) Length-length and length-weight relationships for 13 shark species from the western North Atlantic. US Dep Commer, NOAA Tech Memo NMFS NE 110, NOAA, Washington, DC

Lasta CA (2003) Mesa de debate sobre condrictios de Argentina y Uruguay. Frente Mar 19B:195-198

> Lucifora LO, Valero LJ, García VB (1999) Length at maturity of the greeneye spurdog shark, Squalus mitsukurii (Elasmobranchii: Squalidae), from the SW Atlantic, with comparisons with other regions. Mar Freshw Res 50: 629-632

Mabragaña E (2007) Las rayas del género Psammobatis de la Plataforma Argentina: biología y ecología. PhD dissertation, Universidad Nacional de Mar del Plata
Mabragaña E, Cousseau MB (2004) Reproductive biology of two sympatric skates in the Southwest Atlantic: Psammobatis rudis Gunther, 1870 and P. normani McEachran, 1983. J Fish Biol 65:559-573

- Mabragaña E, Giberto D (2007) Feeding ecology and abundance of two sympatric skates, the shortfin sand skate Psammobatis normani McEachran, and the smallthorn sand skate $P$. rudis Günther (Chondrichthyes, Rajidae), in the Southwest Atlantic. ICES J Mar Sci 64:1017-1027

Menni R, Lucifora L (2007) Condrictios de la Argentina y Uruguay: lista de trabajo. Serie Técnica y Didáctica 11, ProBiota, Mar del Plata

Menni RC, Stehmann FW (2000) Distribution, environment and biology of batoid fishes off Argentina, Uruguay and Brazil. A review. Rev Mus Argent Cienc Nat Bernardino Rivadavia Inst Nac Invest Cienc Nat 2:69-109

Menni RC, Gosztonyi AE, López HL (1979) Sobre la ecología y biología de 'Halaelurus bivius' (Chondrichthyes, Scyliorhinidae). Rev Mus Argent Cienc Nat Bernardino Rivadavia Inst Nac Invest Cienc Nat 2:71-88

Menni RC, López HL, García ML (1981) Lista comentada de las especies de peces colectadas durante la campaña V del B/P 'Shinkai Maru' en el Mar Argentina (1978). In: Contribuciones del Instituto Nacional de Investigación y Desarrollo Pesquero, Vol 383, p 267-280

Menni R, Ringuelet R, Arámburu R (1984) Peces marinos de la Argentina y Uruguay. Hemisferio Sur, Buenos Aires

> Menni RC, Jaureguizar AJ, Stehmann MFW, Lucifora LO (2010) Marine biodiversity at the community level: zoogeography of sharks, skates, rays and chimaeras in the southwestern Atlantic. Biodivers Conserv 19:775-796

> Pájaro M, Macchia GJ, Martos P (2005) Reproductive pattern of the Patagonian stock of Argentine hake (Merluccius hubbsi). Fish Res 72:97-108

Perez Comesaña JE, Perrier MR, Di Giacomo E, Coller NM and others (2011) ¿Cuánto sabemos sobre la biología de los condrictios del Mar Argentino? Reseña de las actividades realizadas por el Grupo Biología. In: Wohler OC, Cedrola P, Cousseau MB (eds) Contribuciones sobre biología, pesca y comercialización de tiburones en la Argentina. Aportes para la elaboración del Plan de Acción nacional. Consejo federal pesquero, Buenos Aires, p 9-24

> Perier R, Estalles M, Coller M, Di Giacomo E (2011) Reproductive biology of the endemic skate Psammobatis lentiginosa in the San Matías Gulf (south-western Atlantic). J Mar Biol Assoc UK 91:1165-1173

> Ruocco NL, Lucifora LO, Díaz de Astarloa JM, Wöhler O (2006) Reproductive biology and abundance of the white-dotted skate, Bathyraja albomaculata, in the Southwest Atlantic. ICES J Mar Sci 63:105-116

> Ruocco NL, Lucifora LO, Díaz de Astarloa JM, Menni RC, Mabragaña E, Giberto DA (2012) From coexistence to competitive exclusion: Can overfishing change the outcome of competition in skates (Chondrichthyes, Rajidae)? Latin Am J Aquat Res. 40:102-112

Sánchez F, Marí NR, Bernardele JC (2009) Distribution, relative abundance and feeding of narrow-mouthed catshark Schroederichthys bivius Müller \& Henle, 1838 in the Southwest Atlantic Ocean. Rev Biol Mar Oceanogr 44:453-466 (in Spanish, with English Abstract)

Sánchez RP, Navarro G, Calvo E, del Castillo F (2011) La pesca y comercialización de condrictios en la Argentina. Aportes de la Dirección Nacional de Planificación Pesquera para la elaboración del Plan Nacional. In: Wohler OC, Cedrola P, Cousseau MB (eds) Contribuciones sobre 
biología, pesca y comercialización de tiburones en la Argentina. Aportes para la elaboración del Plan de Acción nacional. Consejo federal pesquero, Buenos Aires, p 151-184

Scenna LB (2011) Biología y ecología reproductiva de las especies del género Bathyraja, en la plataforma continental Argentina. PhD dissertation, Universidad Nacional de Mar del Plata

Shepherd TD, Myers RA (2005) Direct and indirect fishery effects on small coastal elasmobranchs in the northern Gulf of Mexico. Ecol Lett 8:1095-1104

Sosinski J (1978) Characteristics of the North Sea spurdog (Squalus acanthias L.) stock. Fish Biol 8:9-22

Sparre P (1991) Introduction to multispecies virtual population analysis. ICES Mar Sci Symp 193:12-21

Editorial responsibility: Brent Stewart,

San Diego, California, USA
Stevens JD, Bonfil R, Dulvy NK, Walker PA (2000) The effects of fishing on shark, rays, and chimaeras (chondrichthyans), and the implications for marine ecosystems. ICES J Mar Sci 57:476-494

Vooren CM, Da Silva KG (1991) On the taxonomy of the angel sharks from southern Brazil, with the description of Squatina occulta sp.n. Rev Bras Biol 51:589-602

Wöhler OC, Cedrola P, Cousseau MB (2011). Contribuciones sobre biología, pesca y comercialización de tiburones en la Argentina. Aportes para la elaboración del Plan de Acción Nacional. Consejo Federal Pesquero, Buenos Aires

Zhou S, Smith ADM, Punt AE, Richardson AJ and others (2010) Ecosystem-based fisheries management requires a change to the selective fishing philosophy. Proc Natl Acad Sci USA 107:9485-9489

Submitted: January 16, 2013; Accepted: August 19, 2013 Proofs received from author(s): October 7, 2013 